\title{
Development of Mathematics Teaching Materials through Model Eliciting Activities (MEA) to Improve Mathematical Representation Skills of SMA Negeri 1 Lubukpakam
}

\author{
Siti Halima Siregar \\ State University of Medan \\ Medan, Indonesia \\ sitihalima075@gmail.com \\ Izwita Dewi \\ State University of Medan \\ Medan, Indonesia \\ Yulita Molliq \\ State University of Medan \\ Medan, Indonesia
}

\begin{abstract}
Abstrak- This study aims to : 1) Get learning materials mathematics with model eliciting activities who meet the criteria are effective; 2) Describe the improvement of mathematics representation ability of students using the learning materials developed. The research is development research by using four $-\mathrm{D}$ model done 4 stage, that were define, design, develop, and disseminate. The subject of this research were the ten grade students of SMA Negeri 1 Lubukpakam. The teaching materials that resulted from this research are: teacher's book (BPG), student's book (BS), and student's worksheet (LAS). From the results of trial I and II trial obtained: 1) teaching materials based MEA developed have meet the effective criteria in terms of their respective criteria; 2) there is improvement of students mathematical representation ability by using teaching materials based MEA developed in trial I obtain average pretest score $57,56 \%$ and posttest score $74,87 \%$, and increase in trial II with average pretest score $58,85 \%$ and posttest score $84,02 \%$.
\end{abstract}

Keywords: Development, Learning Materials, Mathematical Representation Skill, Model Eliciting Activities

\section{INTRODUCTION}

Education plays an important role in life to prepare qualified, qualified and competent human resources. Quality human resources are certainly produced by a quality education system, that is "... the quality of the education system of a nation determines the caliber and quality of its human resource" [4].

Mathematics is one of the subjects in school that can be used to achieve that goal. Mathematics is a universal science underlying the development of modern technology, has an important role in various disciplines and develop the human mind power [1]. Mathematics is a necessary means of scientific thinking to foster the ability to think logically, systematically, and critically in students. And mathematics is needed by everyone in everyday life.

The Council of Teachers of Mathematics (NCTM) [1] states that: School mathematical standards include mathematical content and process standards (mathematical processes). Process standards include problem solving, reasoning and proof, connections, communication, and representation. The standards of the process together constitute the basic skills and understanding students need in the 21 st century.

One of the abilities that students need is the ability of representation. The ability of a mathematical representation is the ability to express mathematical ideas (problems, statements, solutions, definitions, etc.) into one form: (1) Drawings, charts, or tables; (2) mathematical notation, numerical / algebraic symbol; and (3) Written text / words, as an interpretation of his mind [3].

But in fact, this mathematical representation is still a part that gets noticed. The limited knowledge of teachers and the habits of students learning in the classroom in a conventional way has not been 
possible to cultivate or develop optimal student representation power [2].

There is a study aimed at detecting students' difficulties in solving mathematical problems from their teacher's perspective. The results show that "the student's difficulties are mostly sprung from their disabilities in representation and understanding of the problem word, making a plan and defining the related vocabularies." [6].

One of the factors causing the learning of mathematics has not been satisfactory is the learning process that has not run well as lack of planning in the learning process so that learning activities less well realized. To facilitate teachers in the learning process and facilitate students in learning, teachers need to organize the material which is then developed into teaching materials.Dick, et al mention that the essence of teaching materials is "The instructional materials contain the content-written, mediated, or facilitated by an instructor-that a student will use to achieve the objective ". [5] Given the benefits of the use of teaching materials, it is very important that the development of instructional materials in accordance with the needs of students. Teaching materials are all forms of materials that can be used by teachers to assist in conducting classroom learning activities.

In order for learning to be easy, interesting, and useful for students, teachers should start learning by introducing problems from the student environment (contextual issues) [10]. One of the lessons that started with the introduction of problems was through the Model Eliciting Activities (MEA) Approach. Model-eliciting tasks (MEAs) are complex, open, non-routine problems in a variety of real world contexts that can interact between their informal and more formal mathematical knowledge [9] . In addition to presenting a realistic problem, learning with the MEA approach involves the activity of creating a mathematical model. Mathematical model can be interpreted as a presentation of a situation or objects in mathematical form.

Based on the description, this research aims to: 1) acquire mathematics teaching materials with eliciting activities model (MEA) that meet the effective criteria; 2) describe the improvement of students' mathematical representation through the use of developed teaching materials.

\section{RESEARCH METHOD}

This research is a development research using model of development of Thiagarajan, Semmel and Semmel device, that is 4-D model (define, design, develop, disseminate) [8]. This research was conducted to produce the necessary teaching materials which will then be tested in class. So that the product of this study is teaching materials (textbooks and LKS) with effective Eliciting Activities (MEA) model with the aim to improve students' representation and mathematical skills.
Subjects in this study were students of class $\mathrm{X}$ SMA 1 Lubukpakam academic year 2016/2017. The object in this study was to look at the quality (valid, practical and effective) teaching materials developed with MEA on trigonometric material.

Instrument or data collection tool in this research is test. The test is used to measure students' mathematical representation abilities. Furthermore, to see the effectiveness of teaching materials viewed from:

a. Student's learning completeness in classical, that is analyzed by considering that student is said to be complete if individual student value reaches $65 \%$, while a learning is said to have finished classically that if there is $85 \%$ of students who follow the test has been completed [hasratuddin].

b. Student activity, that is during learning activity is analyzed based on percentage of student activity ideal time where the percentage of student activity is frequency of every aspect of observation divided by total frequency all observation aspect multiplied by $100 \%$.

c. Implementation of learning, which is taken from the average score score assessment of learning effectiveness is converted as follows:

$R S P=\frac{\sum x}{n}$

Information :

$R S P=$ Average Rating Score

$x=$ Scoring score

$n \quad=$ Number of assessment aspects

The implementation of learning using teaching materials is said to be effective when the average teacher's ability for all meetings reaches a minimum of either $(2.50 \leq \mathrm{RSP}<3.50)$.

d. Questionnaire responses of students were analyzed by calculating the percentage of many students who responded positively to each of the categories asked in the questionnaire by using the following formula:

$\mathrm{PRS}=\frac{\sum \mathrm{A}}{\sum \mathrm{B}} \mathrm{x} 100 \% \quad[8]$

Students have a positive response to learning tools developed when the number of students who responded positive members greater or equal to $80 \%$ of the many subjects studied for each trial [7].

Information :

PRS : Percentage of many students who respond positively to each of the categories asked

$\sum \mathrm{A}$ : Proportion of students who choose

$\sum \mathrm{B}$ : Number of students (respondents) 


\section{RESEARCH RESULT AND DISCUSSION}

1. Description of Stage of Material Development with Model Eliciting Activities.

The researcher conducted a research on development of teaching materials with 4-D development model (Four-D Model) proposed by Thiagarajan, Semmel and Semmel. The first stage begins with the define, the second stage is design, the third stage is development and the last stage is dissemination. The results of the development of such teaching materials can be described as follows:

\section{a. Definition Stage (define)}

1) Final Beginning Analysis

Based on observations made by researchers obtained textbooks used are not associated with the daily life of students and the presentation of questions is still less support in improving students' mathematical representation. Furthermore, LKS has not been utilized in SMA Negeri 1 Lubukpakam so that students are poorly trained in sharpening mathematical skills and less active in learning activities.

\section{2) Student Analysis}

Researchers conducted observations to SMA Negeri 1 Lubukpakam, by giving math problems to 32 students of class XI MIPA 3 who have studied the material of Sinus and Cosinus Rules. Once analyzed, students can work on mathematical representation problems, but in terms of representation in the form of images (visual representation) and to translate the problem to the model of mathematics (verbal representation) students have difficulty. Through the answers of students in solving problems obtained as much as $60 \%$ of students are weak in utilizing the ability of mathematical representation that students have.

\section{3) Concept Analysis}

The subject matter used in this research is Trigonometry material for high school class $\mathrm{X}$ with reference to Curriculum 2013. Trigonometric material is limited only to Sinus and Cosinus Rules.

4) Task Analysis

The results of the task analysis performed were the tasks of the students at the time of learning by using learning tools developed, that is to find the concept of sinus rules, find the concept of cosine rules, use the concept of sinus rules in solving problems, and use the concept of cosine rules in solving problems.

\section{5) Formulation of Learning Objectives}

The activity in this step is to outline indicators of achievement of learning outcomes into more specific indicators that are tailored to core competencies and basic competencies in the 2013 curriculum can be seen in Table 1.
Table 1. Sub Topics and Learning Objectives

\begin{tabular}{|l|l|}
\hline \multicolumn{1}{|c|}{$\begin{array}{c}\text { Sub } \\
\text { Topics }\end{array}$} & \multicolumn{1}{c|}{ Learning Objectives } \\
\hline $\begin{array}{l}\text { Rules of } \\
\text { sine }\end{array}$ & $\begin{array}{l}\text { 1. Discover the concept of sine rules. } \\
\text { 2. Complete the calculation problem } \\
\text { using the sine rules. } \\
\text { 3. Complete the mathematical model of } \\
\text { everyday problems related to sine rules. }\end{array}$ \\
\hline $\begin{array}{l}\text { Rules of } \\
\text { cosines }\end{array}$ & $\begin{array}{l}\text { 1. Discover the concept of cosine rules. } \\
\text { 2. Complete the calculation problem } \\
\text { using cosine rules. } \\
\text { 3. Complete the mathematical model of } \\
\text { everyday problems related to cosine } \\
\text { rules. }\end{array}$ \\
\hline $\begin{array}{l}\text { Triangular } \\
\text { area }\end{array}$ & $\begin{array}{l}\text { 1. Finding the broad concept of } \\
\text { triangles by utilizing the concept of sine } \\
\text { rules } \\
\text { 2. Calculate the area of a triangle whose } \\
\text { components are known. } \\
\text { 3. Complete the mathematical model of } \\
\text { everyday problems related to the area of } \\
\text { the triangle. }\end{array}$ \\
\hline
\end{tabular}

b. Design Stage (design)

1) Preparation of the Test

The test used is a test of mathematical representation ability.

2) Selection of Media and Tools

Media and teaching aids used are paper, pen, pencil, ruler, eraser.

\section{3) Format Selection}

The textbook format refers to the rules of BSNP (National Education Standards Agency). Textbooks and LKS are colored so that students will be interested and motivated to learn.

\section{4) Initial Design}

In the initial design stage, the initial draft of instructional materials in the form of Learning Implementation Plan (RPP), Textbook, and LKS for 3 (three) meetings, mathematical representation test, scoring guidance, and answer. All the results of this design stage are here in after referred to as draft 1.

\section{c. Development Stage}

The results of the define and design stage resulted in the initial design of a learning tool called draft 1. After the learning tool based on realistic mathematical approach designed in the form of draft 1 , the validity test of the expert review and field trial was conducted.

\section{1) Validation Results}

Before learning tools and research instruments are piloted, first learning tools and research instruments are validated to five validators including experts in the field. From the validation results, the learning device criteria and research instruments developed are "valid" and can be used with small revisions. Furthermore, the test of students' mathematical representation ability, tested in the class outside the sample, then tested the validity and reliability. 


\section{2) Trial 1}

Once the learning device developed has met the valid criteria. Then the next learning device in the form of draft II is tested in place of research that is test I conducted in class X-IPS 2 SMA Negeri 1Lubukpakam. The result of analysis of trial data $I$ is instructional device not yet effective, because there are still some indicator of effectiveness that have not reached that is result of classical completeness representation ability and student activity on trial 1 can be seen in Table 2 .

Table 2. Description of Results of Ability of Student Mathematical Representation in Trial 1

\begin{tabular}{|c|c|}
\hline Information & $\begin{array}{c}\text { Mathematical } \\
\text { Representation Ability } \\
\text { Posttest }\end{array}$ \\
\hline Highest score & 86,67 \\
\hline Lowest score & 60,00 \\
\hline Average & 75,12 \\
\hline $\begin{array}{c}\text { Completeness } \\
\text { Percentage }\end{array}$ & $80,7 \%$ \\
\hline
\end{tabular}

Based on Table 2 it can be seen that the average class for the test of mathematical representation ability in test 1 is 75.12 with the percentage of students' learning completeness in classical that is $80,7 \%$ from 26 students. This states that the student has not fulfilled the classical thoroughness value.

In addition, the percentage of student activity time for three meetings is described briefly in Table 3 . Table 3. Average Percentage of Ideal Time Student Activity Trial 1

\begin{tabular}{|c|c|c|c|c|c|}
\hline \multirow{2}{*}{ Meeting } & \multicolumn{5}{|c|}{$\begin{array}{c}\text { Average Percentage of Ideal Time } \\
\text { Achievement of Student Activities } \\
\text { For Each Category (\%) }\end{array}$} \\
\cline { 2 - 6 } & $\mathbf{1}$ & $\mathbf{2}$ & $\mathbf{3}$ & $\mathbf{4}$ & $\mathbf{5}$ \\
\hline $\mathbf{1}$ & 24.2 & 19.6 & 24.84 & 27.45 & 5.63 \\
\hline $\mathbf{2}$ & 26.21 & 19 & 25.01 & 25.57 & 4.21 \\
\hline $\mathbf{3}$ & 23.24 & 19.7 & 25.24 & 25.26 & 6.56 \\
\hline
\end{tabular}

Based on Table 3, it can be seen that the highest percentage of time spent by students is $26.09 \%$, the students' learning activities are more dominant to spend time to discuss / ask between students and their friends, and between students and teachers, drawing conclusions from a procedure or concept. While the proportion of time is at least seen in the fifth activity, ie the activity of students who are not relevant to the learning of $5.46 \%$. Overall there is still average ideal time percentage of student activity that has not reached the percentage of ideal time set $(0 \% \leq \mathrm{PWI} \leq$ $5 \%)$ ie on the aspect of the category of doing something that is not relevant to the learning of $5.46 \%$. Thus it can be concluded that the teaching field developed by MEA has not been effective in terms of student activity.

Based on the results of analysis and test I, it is necessary to revise some component of teaching materials developed in the hope that learning tools can improve students' mathematical representation.

\section{3) Trial 2}

After conducting pilot I in draft II, further improvements are made to produce learning devices that meet the good effectiveness. The result of revision in trial I produced draft III which will be tested on XIPS - 1SMA Negeri 1 Lubukpakam students. These 2 trials were conducted three times in accordance with the learning implementation plan (RPP) that has been developed. Test 2 was conducted to measure the effectiveness of learning tools (draft III) developed with MEAs aimed at improving students' mathematical representation. Overall, the classical completeness level of students' mathematical representation ability in trial 2 can be seen in Table 4 .

Table 4. Description of Results of Ability of Student Mathematical Representation in Trial 2

\begin{tabular}{|c|c|}
\hline Information & $\begin{array}{c}\text { Mathematical } \\
\text { Representation Ability } \\
\text { Posttest }\end{array}$ \\
\hline Highest Score & 96,67 \\
\hline Lowest Score & 63,33 \\
\hline Average & 84,02 \\
\hline $\begin{array}{c}\text { Completeness } \\
\text { Percentage }\end{array}$ & $93 \%$ \\
\hline
\end{tabular}

Based on Table 4 it can be seen that the average class for the test of mathematical representation ability in experiment 1 is 84.02 with the percentage of students' learning completeness classically that is $93 \%$ from 29 students. It is stated that the students have fulfilled the classical thoroughness value.

Furthermore, the implementation of learning, student response has been achieved and positive. Likewise, the ideal time of student activity used has been in accordance with the criteria of learning time attainment. Thus it can be concluded that the learning device developed with MEA in trial II which is a revision of trial I has met the quality of effective learning tools.

\section{d. Disseminate Stage}

Teaching materials developed with MEA in the deployment stage are done in a limited way only in partner schools only SMA Negeri 1 Lubukpakam. After the final teaching materials, the developed teaching materials are disseminated to be used in the next semester in Trigonometry materials.

2. Improvement of Ability of Student Mathematical

Representation by Using Ajary Material developed with MEA

Based on the result of the improvement of students' mathematical representation in experiments 1 and 2 showed that the improvement of students' mathematical representation ability got the n-gain value in test 1 of 0.41 and the improvement of students' mathematical representation ability got the n-gain value on trial 2 of 0,61 . This shows the ability of students 'mathematical representation using experimental materials developed with MEAs improved in trial 1 and trial 2. Improved students' mathematical representation by using experimental materials based on MEA developed in trial I earned 
an average pretest score $57,56 \%$ and posttest score $75,12 \%$, and increase in trial II with mean score of pretest $58,50 \%$ and posttest score $84,14 \%$

The improvement of the ability of mathematical representation exists in the three aspects of the students can present images of mathematical problems, create equations or mathematical models, and solve problems by involving words and mathematical expressions. The average increase in the ability of mathematical representation can be seen in detail in Figure 1.

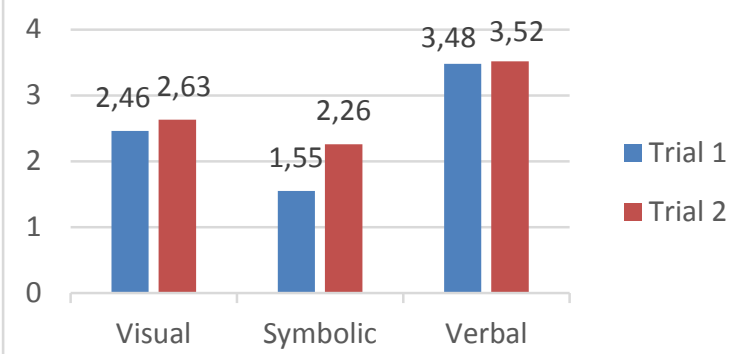

Figure 1. Comparison of students' mathematical representation ability score 1 and trial 2

Increasing the ability of mathematical representation when viewed from each aspect / indicator of mathematical representation ability, mean of student's mathematical representation ability to visual aspect that is student able to present picture from problem having increase equal to 0,17 , mean of ability of student mathematical representation for symbolic aspect that is students are able to create equations or mathematical models of problems experienced an increase of 0.71 and the average ability of students' mathematical representation for verbal aspects ie students able to solve problems by involving words and mathematical expressions increased by 0.04 .

\section{CONCLUSION}

Based on the results of data analysis and implementation of research during learning mathematics with realistic and conventional approach with emphasis on the ability of students' mathematical creative thinking, the researchers obtained the following conclusions:

1. Teaching materials developed with Model Eliciting Activities (MEA) meet the criteria effectively. Effective criterion is observed from: (1) student's learning completeness has been classically achieved in trial 2 that is equal to $93 \%$; (2) the ability of teachers in managing learning is in the category both in trial 1 and trial 2 ; and (3) there is no difference between the achievement of learning time using the teaching materials developed with ordinary learning.

2. Improved ability of mathematical representation of students using teaching materials developed with Model Eliciting Activities (MEA) on Trigonometric material is in the medium category .. Improvement of mathematical representation capability obtained by using $\mathrm{N}$ gain, which in trial 1 improvement of student's mathematical representation ability obtained by 0.41 and on trial 2 the improvement of students 'mathematical representation capability was obtained by 0.61 . The improvement of students' mathematical representation ability by using the experimental materials based on MEA developed in experiment I obtained the mean of pretest score $57,56 \%$ and score posttest $75.12 \%$, and increased in trial II with an average pretest score of $58.50 \%$ and posttest score of $84.14 \%$.

\section{REFERENCES}

[1] Hasratuddin. 2015. Mengapa Harus Belajar Matematika?. Medan: Perdana Publishing

[2] Hudiono, B. 2010. Peran Pembelajaran Diskursus Multirepresentasi Terhadap Pengembangan Kemampuan Matematika Dan Daya Representasi Pada Siswa SLTP. Jurnal Cakrawala Kependidikan Vol. 8 No. 2: 101-110

[3] Kartini. 2009. Peranan Representasi Dalam Pembelajaran Matematika. Prosidig Seminar Nasional Matematika dan Pendidikan Matematika Jurusan Pendidikan Matematika FMIPA UNY 05 Desember 2009. ISBN: 978-979-16353-3-2.

[4] Kayode, A., Kajang, T.J. \& Anyio, S.F. 2013. Human Resource Development and Educational Standard in Nigeria.Global Journal of Human Social Scince Linguistics \& Education, Volume 13 Issue 2 ISSN: 2249-460X

[5] Mukhtar. 2013. Pengembangan Bahan Ajar Matematika Berbasis Masalah untuk Memfasilitasi Pencapaian Kemampuan Penalaran dan Pemahaman Konsep Siswa. Prosiding Semirata FMIPA Universitas Lampung. Hal 353360

[6] Seifi, M., Haghverdi, M., dan Azizmohamadi, F. 2012. Recognition of Students' Difficulties in Solving Mathematical Word Problems from the Viewpoint of Theachers.Journal of Basic and Apllied Scientific Research 2 (3) 2923-2938, 2012 ISSN: 2090-4304

[7] Sinaga, B. 2007. Pengembangan Model Pembelajaran Matematika Berdasarkan Masalah Berbasis Budaya Batak (PBM-B3). Disertasi. Surabaya: Program Pascasarjana Universitas Negeri Surabaya

[8] Trianto. 2013. Mendesain Model Pembelajaran Inovatif Progresif. Jakarta: Kencana

[9] Wessels, H. 2014. Level of Mathematical Creativity in Model-Eliciting Activities. Journal of Mathematical Modelling and Application Vol. 1. No. 9, 22-40 ISSN: 21782423

[10] Yuwono, I. 2014. Pendidikan Matematika Dan Pendidikan Karakter Dalam Implementasi Kurikulum 2013. Prosiding Seminar Nasional Pendidikan Matematika, Program Pascasarjana STKIP Siliwangi, Bandung, 15 Januari 2014, (1) $: 1-3$ 